\title{
Nanocarriers-Mediated Drug Delivery Systems for Anticancer Agents: An Overview and Perspectives [Corrigendum]
}

\author{
Edis Z, Wang J, Waqas MK, Ijaz M, Ijaz \\ M. Int J Nanomedicine. 2021;16:1313-1330. \\ Medical College for Nationalities" should read \\ "Affiliated Hospital of Youjiang Medical University for \\ Nationalities".
}

The authors have advised affiliation 3 on page 1313 is incorrect. The text "Affiliated Hospital of Youjiang
The authors apologize for this error.

\section{Publish your work in this journal}

The International Journal of Nanomedicine is an international, peerreviewed journal focusing on the application of nanotechnology in diagnostics, therapeutics, and drug delivery systems throughout the biomedical field. This journal is indexed on PubMed Central, MedLine, CAS, SciSearch ${ }^{\mathbb{B}}$, Current Contents ${ }^{\mathbb{B}} /$ Clinical Medicine,
Journal Citation Reports/Science Edition, EMBase, Scopus and the Elsevier Bibliographic databases. The manuscript management system is completely online and includes a very quick and fair peer-review system, which is all easy to use. Visit http://www.dovepress.com/ testimonials.php to read real quotes from published authors. 